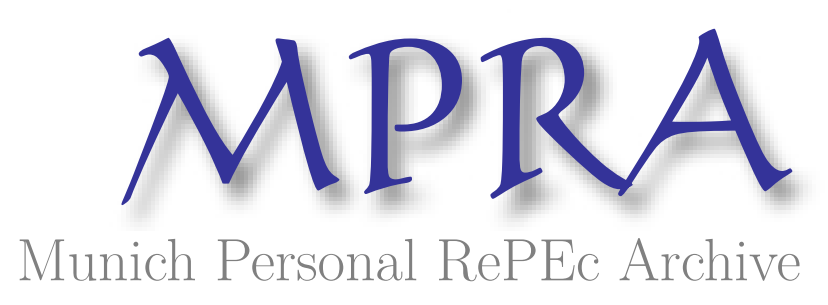

\title{
Higher education corruption in the world media: Prevalence, patterns, and forms
}

Osipian, Ararat

Vanderbilt University

15 November 2007

Online at https://mpra.ub.uni-muenchen.de/8475/

MPRA Paper No. 8475, posted 26 Apr 2008 02:55 UTC 


\section{Higher Education Corruption in the World Media: \\ Prevalence, Patterns, and Forms}

Ararat L. Osipian

Osipian, A. Higher Education Corruption in the World Media: Prevalence, Patterns, and Forms). $32^{\text {nd }}$ Annual Conference of the Association for the Study of Higher Education (ASHE), Louisville, KY, November 2007.

Contact: ararat.osipian@vanderbilt.edu; araratos@yahoo.com 


\section{Introduction}

Corruption in higher education is a newly emerging topic in the field of education research. Some aspects of corruption in education have been addressed in recent works by Martin Anderson (1992), Melissa Anderson (1999, 2001), Max Eckstein (2003), Jacques Hallak and Muriel Poisson (2002, 2007), Stephen Heyneman (2004), Harold Noah and Max Eckstein (2001), Lydia Segal (2004), and Jennifer Washburn (2005). Scholarly work on corruption in higher education is lacking while the problem itself is significant. The presence of corruption in higher education throughout the world is a growing concern for the industry as it influences its effectiveness and efficiency. ${ }^{1}$ The negative impact of higher-education corruption on economic development and social cohesion is also disturbing. ${ }^{2}$ With the rapid internationalization of higher education and the growing volume of trade in educational services, matters of educational credentials--and credibility in general--become ever more important. ${ }^{3}$

The three major issues in higher education are access, quality, and equity. These issues are universal and at stake in every nation. Corruption affects all three of these issues. It has a negative impact on the quality of higher education and other services; it increases inequality in access to higher education, and causes inequities. Every nation solves problems of access, quality,

${ }^{1}$ There are numerous media sources that include publications focused on different aspects of corruption in higher education internationally. An excellent selection of media titles devoted to corruption in higher education may be found at the Center for International Higher Education at Boston College.

${ }^{2}$ See, for instance, Silova, Iveta, Mark Johnson and Stephen Heyneman. 2007. Education and the Crisis of Social Cohesion in Azerbaijan and Central Asia. Comparative Education Review, 51(2) (May): 159-180.

${ }^{3}$ See, for instance, Altbach, Philip, and Jane Knight. 2006. The Internationalization of Higher Education: Motivations and Realities. In The NEA Almanac of Higher Education. Washington, DC: National Education Association.; De Wit, Hans. 2002. Internationalization of Higher Education in the United States and Europe: A Historical, Comparative, and Conceptual Analysis. Westport, CT: Greenwood. For the issue of international credentials recognition see Heyneman, Stephen, Kathryn Anderson, and Nazym Nuraliyeva. 2007. "The Cost of Corruption in Higher Education." Comparative Education Review, forthcoming: 26. 
and equity differently. Thus, also corruption in higher education is part of the news in every country, ways in which the national media reflects on corruption in higher education differ.

This paper considers corruption in higher education as reflected in the world media, including such aspects of corruption as its prevalence, patterns, and dominating forms. The findings help to determine which aspects of corruption should be given more consideration in future research and which ones might be prioritized.

\section{Defining corruption in higher education}

The word corruption comes from the Latin word corruptio, which in Medieval Latin expressed a moral decay, wicked behavior, putridity, rottenness (Johnston 1996, 322). Milovanovic (2001) says that in this context one could talk of bribes, or other dishonest means for achieving particular disgraceful ends, as a symptom of an ailing society. Johnson's Dictionary defines bribe as "a reward to pervert the judgment or corrupt the conduct," while corruption is "a loss of purity and purpose, a social decomposition." (Osborne 1997, 10) Transparency International uses a clear and focused operational definition of corruption as the misuse of entrusted power for private gain. ${ }^{4}$

Duncan White and David Allen point out that "Agreed upon definitions are rare, and definitions of corruption run the gamut of being too broad to be rendered relatively useless to being to narrow and thus be applicable to only limited, rare, well-defined cases." (White and Allen 2003, 282) The discussion of corruption is field specific. The literature in political science focuses on corruption in public policy. It includes rent-seeking behavior (Krueger 1974; Klitgaard 1986; White 1996; McChesney 1997), the rise of state bureaucracies (Wilson 1975;

\footnotetext{
${ }^{4}$ Transparency International, 2007. Retrieved June 22, 2007, from http://www.transparency.org/news_room/faq/corruption_faq
} 
Weber 1978), and cross-national characteristics (Treisman 2000). The definition most cited in the political literature is given by Joseph Nye: "Corruption is behavior which deviates from the normal duties of a public role because of private-regarding (family, close private clique), pecuniary or status gains, or violates rules against the exercise of certain types of privateregarding influence. This includes such behavior as bribery (use of reward to pervert the judgment of a person in a position of trust); nepotism (bestowal of patronage by reasons of ascriptive relationship rather than merit); and misappropriation (illegal appropriation of public resources for private-regarding use).” (Nye 1967, 419)

Economics has advanced significantly in modeling corruption, but is experiencing difficulties in testing the models due to the lack of large and reliable datasets (Rose-Ackerman 1978; Tirole 1992; Bardhan 1997). Whatever problem economists might have in explaining corruption is indicated by Susan Rose-Ackerman's (1978) definition of corruption as an "allocative mechanism" for scarce resources. The state monopolizes certain allocative functions, be it permissions and licenses, or access to public services. State officials' profiteering is based on abuse of their discretionary powers and monopolistic positions.

The definition of education corruption includes abuse of authority for material gain (Anechiarico and Jacobs 1996). Heyneman adds to this definition by arguing the following: "But because education is an important public good, its professional standards include more than just material goods; hence the definition of education corruption includes the abuse of authority for personal as well as material gain.” (Heyneman 2004, 638) Seumas Miller, Peter Roberts, and Edward Spence point to the relativeness of the term corruption and apply it to academia:

The notion of a corrupt official or other role occupant exists only relative to some notion of what an uncorrupted occupant of that morally legitimate role consists of. The notion of 
an academic has at its core the moral ideal, or at least, the morally legitimate role, of an independent truth-seeker who works in accordance with accepted principles of reason and evidence, who publishes in his or her own name only work that he or she has actually done, and so on. So an academic motivated by a desire for academic status who intentionally falsifies his or her experimental results or plagiarizes the work of others is corrupt relative to the ideal or morally legitimate role of an uncorrupted academic. On the other hand, a person occupying an academic position who paid no heed whatsoever to the truth or to principles of reasoning and evidence and who made no pretense of so doing would at some point cease to be an academic of any sort, corrupt or otherwise (Miller, Roberts, and Spence 2005, 5).

The International Institute for Educational Planning (IIEP) offers defining corruption in education as a "misuse of public office for private gain that influences access, quality, and equity in education." Taleh Sayed and David Bruce (1998) and Waite and Allen (2003) present a broad social approach to define corruption. This article adheres to Georgy Petrov and Paul Temple's (2004) approach to corruption and applies narrow definition of corruption that regards corruption as such only if it implies illegality. It uses operational definition of corruption in higher education as a system of informal relations established to regulate unsanctioned access to material and nonmaterial assets through abuse of the office of public or corporate trust.

National laws differ and legality and illegality are not universal. Accordingly, there might be not one universal definition of corruption in higher education that would apply equally well to different national systems in different historical periods. Granting access to publicly funded higher education on any premise other than academic merit is equated to corruption. Access to

\footnotetext{
${ }^{5}$ The International Institute for Educational Planning (IIEP), http://www.unesco.org/iiep/eng/research/research.htm
} 
higher education in exchange for a bribe is deemed to be corrupt. In the decentralized marketbased systems of higher education, gaining access to educational services in exchange for payments is a norm. Depending on the system and legal frameworks laid in the society, certain forms of funding, modes of operation, patterns of behavior, and standards of conduct in higher education may be considered corrupt or non-corrupt. Corruption in higher education is time and place specific and may be found in public and private higher education institutions.

\section{Research question}

The research of corruption in higher education does not face the lack of methodological approaches, as they may be borrowed from other disciplines, including political sciences and economics. At the same time methodological approaches, borrowed from other disciplines and applied to corruption, have certain limitations. Petrov and Temple (2004) say that methodology of studying corruption in education may be no different from qualitative research. However, some problems are encountered by the researchers. For instance, faculty members know of each other's corrupt activities but do not discuss them. As a result, major difficulties arise when collecting information due to specifics of the topic — corrupt practices remain illegal. The authors describe this problem in higher education systems in the Russian Federation by noting the following: "Our own experiences in our region of study suggest that even the most carefully phrased enquiry to university members of staff about the existence of corruption in their institution can be taken as a personal insult. This naturally limits the scope of data collection. Students and former university staff members have no difficulty generally in discussing the matter, however." (Petrov and Temple 2004, 87)

Another problem that researchers may face is the low level of reliability of the 
information obtained from surveys and interviews. Not only media reflects perceptions, problems, and trends, but it also shapes perceptions about corruption. Hence, media is important in researching corruption not only as a reflector from which people collect information, but as an instrument of shaping and facilitating corrupt behavior as well. Moreover, it is noticed by several authors that perceptions of the public about corruption lead to an increase in the number of incidences of corruption and the total volume of benefits obtained through corrupt ways (Cabelkova and Hanousek 2004; Tumennasan 2005; Olken 2006). An increase in public perceptions about corruption in higher education facilitates a further increase in corruption as well as the total amount of corrupt benefits accumulated by the college instructors and administration. This underlines importance of the media as a signaling agency that informs the general public about corrupt practices, customs, and norms. Democratic changes and processes of openness and transparency increase the role of the media in the society.

This paper considers corruption in higher education in the media, following publications in the United States (US), the United Kingdom (UK), and the Russian Federation (RF). The research question can be formulated as follows: How is corruption in higher education reflected in the world media, what particular aspects of corruption receive more of the media's attention and why? Specifically, this paper analyses selected publications in two major international languages, English and Russian, for the period of 1998-2007, devoted to corruption in higher education. This recent period has been selected because all of the sources are available on-line and consequently have much broader outreach than they had before. Other research questions include: Which forms of corruption in higher education are given most attention, which ones are underrepresented, and why? How do the media in one region comment on corruption in higher education in other regions? How does the media coverage of corruption in higher education 
correlate with the statistical data on the prevalence of corruption in each region? And how do all of these correlate with the major educational reforms, changes, and socio-economic context in each of the nations in general?

The publications are grouped depending on the particular problem they address. This criterion has been chosen as best addressing the issue of corruption internationally. The groups are as follows: corruption in access to higher education, including violations in national and international educational tests, violations in entry examinations, and bribery; corruption in research and research grants, including violations of the rules of conduct, presentation of results known to be incorrect, fraud, plagiarism, and corruption in obtaining grants; corruption in academic process, including low quality of instruction, unearned diplomas, degrees, and educational certificates, cheating, plagiarism, collusion, diploma fraud, production, distribution, sale, and usage of fraudulent certificates, diploma mills, term papers for sale, including those exchanged through the internet; corruption in auxiliary activities, including intercollegiate athletics; industry-specific corruption in higher education management and administration, including fraud, embezzlement, and provision of false information; corruption in auxiliary branches, including academic publishing, development and provision of educational software, and supply of educational services and goods.

Different aspects of corruption in higher education are reflected in just about every news source or edition. The research has chosen sources that provide the most comprehensive reflection on both nationwide and international problems, including the entire spectrum of the problems associated with higher education corruption. These sources consider significant cases of corruption, broadly discussed in the society. They present stories built of information obtained from reliable sources and have a high level of credibility. 


\section{Research methodology}

This research identifies one source that specializes in higher education and one major news source for each of the regions, including North America (the US), Europe (the UK), and the former Soviet Union (the RF) with populations of approximately 300, 60, and 150 million, respectively. These countries represent different models of higher education organization, including such key aspects as governance, management, funding, and admission policies. The selected on-line non-scholarly publications in the US and the UK can be accessed only for a fee, while publications in the Russian Federation are accessible for free. All of the publications are not limited to the national borders, instead having a much broader outreach.

In the US, the focus is on The Chronicle of Higher Education, a specialized edition, and The New York Times, a non-specialized edition; In the UK, this research reports on corruption in higher education in The Times Higher Education Supplement, a specialized edition, and The Guardian, as a non-specialized edition; in the RF, this paper investigates on-line editions of Gazeta.ru, a non-specialized edition that has a substantial regular section on higher education, and Newsru.com, a non-specialized edition. All of the media sources presented above address to a certain extent both domestic and international issues in higher education.

The proposed categorization of corruption in higher education for this study includes means, forms and phenomena, spheres where it exists, and areas of interaction where it is found. The means are: bribes, kickbacks, kinship, personal connections, reciprocity (exchange of favors), and fraud. The forms and phenomena include: bribery, nepotism, favoritism, fraud, embezzlement, cheating, plagiarism, ethics misconduct, and breach of contract. The spheres are: access to higher education, academic process, graduation, credentials, licensing and accreditation, 
faculty hiring and promotion, research, grants, medical services. The interactions include: stateuniversity, business-university, faculty-students, faculty-administration, students-administration, and state-students relations. Classification of corruption in higher education used in this study is presented in Table 1.

/Table 1 appears here/

The research carries some limitations. The areas left unattended in categorization of corruption include gross waste and misallocation of resources. Gross waste and misallocation of resources constitute so-called grey area of corruption in education, especially when personal or material gains are not pursued. Even though gross waste and misallocation of resources is detrimental to higher education, in most of the instances it does not constitute an illegal act, unless personal benefit is pursued. For instance, investments in university presidents' residences and renovations, addressed only in US media, are considered by some as misallocation of the university resources. While the merit of such investment may be arguable, the legality of it stays intact. The same is true for mismanagement in higher education institutions. While systemic mismanagement has a negative impact on the health of academia, it is not considered as an act of corruption as long as it does not include embezzlement, fraud, or other illegal activities.

The key words used in the search within the identified sources include: accreditation, admissions, bribe, bribery, cheating, college, corruption, degrees, diploma mills, education, embezzlement, examinations, fake, favoritism, fraud, higher education, higher education institution (HEI), misconduct, nepotism, plagiarism, research, tests, university, as well as crossreferences of all of the above. Each media report on corruption-related issue in higher education 
is read, analyzed, and assigned a place according to the developed classification. The classification itself is being enriched in the process of analyzing the news on corruption in academia. For instance, the mafia-university relations subcategory is added to the Interactions section of the Classification, based on the reports about the existing connections between the mafia and a higher education institution in Italy. ${ }^{6}$

\section{Major findings}

The following results were obtained based on the detailed description of classification and criteria of corruption in higher education. The media points to the presence of the phenomenon of corruption in the three national systems of higher education. This phenomenon manifests itself in bribery of all types and forms, including offering and accepting money. Bribery is most common in the RF with bribes paid in cash, including in national and foreign currency and through personal account transfers. ${ }^{7}$ Bribes are also offered in form of commodities, including durable goods and non-durable goods, services, and sex. Forms of corruption are not limited to bribery in cash and goods and services. Phenomenon of corruption also includes exchange of favors based on the principle of reciprocity as well as nepotism, including preferential treatment based on kinship. Another form of corruption discussed in the media is favoritism. This includes preferential treatment, based on personal favors.

${ }^{6}$ See Bollag, B. (2000). "The academy and the mob." The Chronicle of Higher Education, (December 1): A51.; Bollag, B. (2000). "37 at Italian university charged with Mafia ties." The Chronicle of Higher Education (November 3): A52.

${ }^{7}$ Lemutkina, Marina. 2004. "50\% roditelej platyat prepodavatelyam vztyatki." [50 percent of parents pay bribes to faculty members] Gazeta.ru (February 17); "V Rossii v 2003 godu roditeli potratili na vziatki 26,5 milliarda rublei na obrazovanie svoih detei." [In Russia in 2003 parents have paid 26.5 billion rubles in bribes for their children's education] Newsru (June 24, 2004); "MVD: vziatki v obrazovanii dohodyat do milliona rublej." [Ministry of the Interior: size of a bribe in education reaches one million rubles] Gazeta.ru (June 10, 2006). 
Fraud as a phenomenon of corruption is known to have few forms. First, there is research fraud that takes place in research universities, where generation of new knowledge is one of the major functions along with teaching and learning. Research fraud occurs when research procedures are adjusted or misused to meet the interest of involved parties, and results are misreported to meet certain expectations. ${ }^{8}$ A well-known form of research fraud in the US and to a lesser extent in the UK is the biasness of pharmaceutical research conducted in universities and funded by pharmaceutical companies. ${ }^{9}$ Data manipulations in medical research may eventually lead to serious consequences for patients.

Second, there is healthcare fraud that takes place in university hospitals, medical centers, and other medical facilities that operate under the auspices of higher education institutions. Healthcare fraud occurs when patients and/or insurance companies are overcharged for the services performed, charged for services not performed, or services are not rendered appropriately according to the set procedures. This type of fraud is not related to academic process per se, unless medical treatment is a part of training for medical students.

Third, fraud in higher education can mean a concealed non-compliance, when federal and state laws are broken for personal and/or institutional benefit. Such cases may be prosecuted under the False Claims Act. For instance, this law was applied to the University of Phoenix in 2007. This private for-profit institution of higher education that operates in multiple locations in

${ }^{8}$ Brainard, J. 2000. "As U.S. releases new rules on scientific fraud, scholars debate how much and why it occurs." The Chronicle of Higher Education (December 8): A26; Guterman, L. 2004. "German university revokes Ph.D. of scientist who falsified data as a Bell Labs researcher." The Chronicle of Higher Education (June 16); Jacobson, J. 2005. "MIT fires biology professor who admitted faking data." The Chronicle of Higher Education, 52(12) (November 11): A13.

${ }^{9}$ Eichenwald, K., and G. Kolata. 1999. “A doctor's drug trials turn into fraud: research for hire." New York Times (May 17): A 16-17; Bernstein, N. 1998. "Charges of research fraud arise at Cornell AIDS lab." New York Times, (September 26): A1, B6. Boseley, S. 1999. "Independent body needed to curb fraudulent research." Guardian Weekly (September 16-22). 
the US and enrolls over fifty thousand students was accused in using enrollment practices and pay-for-performance scales for its admissions officers that would go in contradiction with the federal laws. The non-compliance with the law makes vulnerable those university revenues that come from the federal student financial aid packages. If the lawsuit is lost, the non-compliance can cost the university billions of dollars. ${ }^{10}$

Fourth, fraud exists in the form of managed and biased information flow, including having preferred educational loan providers list, as is the case in many colleges throughout the US. Financial aid officers and college administrators in several states were accused of conflict of interest in expectation of personal and/or institutional benefits, such as possible kickbacks, and profit-sharing in exchange for cooperation with private lenders. ${ }^{11}$ Transgressing rules and procedures may be a commonplace yet not addressed practice, until it amounts to a large-scale problem with a clearly visible negative impact on certain groups of stakeholders and the society in general.

Embezzlement as a phenomenon of corruption in higher education works in two major directions: embezzlement from the university, committed by university employees, and

${ }^{10}$ Van Der Werf, M. 2006. "Federal Appeals Court reinstates False-Claims lawsuit against U. of Phoenix." The Chronicle of Higher Education 53 (4) (September 15) A33. The case contends that the university, which is part of the Apollo Group, a publicly traded corporation, paid recruiters on the basis of how many students they could get to enroll. The U.S. Department of Education prohibits institutions from giving "any commission, bonus, or other incentive payment based directly or indirectly on success in securing enrollments." The university certified that it was in compliance with all federal regulations when it applied for eligibility for Pell Grant funds and other federal money under Title IV of the Higher Education Act.

${ }^{11}$ See, for instance, Field, Kelly, and Josh Keller (2007). "Cuomo Accuses Education Dept. of Lax Oversight of Lenders: In Continuing Scandal, Aid Administrators Develop New Code of Conduct." The Chronicle of Higher Education, 53 (May 4): A33.; Field, Kelly. (2007). "College Board Drops Student-Loan Program." The Chronicle of Higher Education, 54 (September 7): A34. There is total of over 40 publications on the issue of student loans and associated fraud and different defrauding techniques in The Chronicle of Higher Education in 2007. All of these publications are based on the results of the continuing investigation conducted by the Attorney General of the State of New York Mr. Cuomo. 
embezzlement by the university, including misappropriation of research grants from the government. Both of these forms may qualify for white collar crime. ${ }^{12}$

Cheating is yet another phenomenon of corruption, reflected equally in the media in the US, the UK, and the RF. Cheating is committed by students in tests and examinations and by prospective students in entry examinations and national tests regarded as entry examinations. ${ }^{13}$ Cheating should not be considered as a relatively innocent or less explicit form of corruption, as compared to bribery. Buying a term paper on-line often replaces the need to pay a bribe. In this case the faculty member is not involved in corruption, but the student achieves the same goal of receiving unearned grade or admission to a college.

Plagiarism is committed both by students in writing academic papers and by faculty in scholarly writing and research. ${ }^{14}$

${ }^{12}$ One of the investigations reflected in the Newsru reports that former president of the Lugansk branch of the Inter-Regional Academy of Personnel Management (MAUP) embezzled 831.9 thousand UAH. See "Byvshy rector luganskogo filiala MAUP prisvoila 831,9 tysyach griven." CityNews (December 25, 2006). Gazeta.ru reports on the audit of the Russian department of education Oversight, conducted by the Attorney General's Office. The Department is being accused in wasteful spending of around 30 million rubles. See, for instance, Lemutkina, Marina. (2006). "Genprokuratura poshla na ediny ekzamen." [The Attorney General's Office took up on the standardized test] Gazeta.ru (June 6); Lemutkina, Marina. (2006). "Rosobrnadzoru propalili obshak." [Rosobrnadzor lost its sources of illegal income] Gazeta.ru (September 25); Lemutkina, Marina. (2007). "Rosobrvygovor." [Rosobrreprimand] Gazeta.ru (April 9).

${ }^{13}$ See, for instance, Desruisseaux, P. 1999. "Cheating is reaching epidemic proportions worldwide, researchers say." The Chronicle of Higher Education (April 30): A45.; Wilgoren, J. 2000. "Cheating on statewide tests is reported in Massachusetts." The New York Times (February 25); Baty, P. 2004. "Survey shows cheating is rife." The Times Higher Education Supplement (July 2); Henry, J. 2001. "More heads found guilty of tests cheating." The Times Higher Education Supplement (October 8); Reznik, I. 2004. "Vzroslye vrut, shkol'niki spisyvajut." [Adults lie, students cheat] Gazeta.ru (March 23).

${ }^{14}$ US and UK sources were quick on accusing even the Russian President Vladimir Putin of plagiarism. Specifically, they commented on plagiarism in President Putin's doctoral dissertation based on the findings of an American researcher. The Russian sources, including Newsru, picked up these reports and placed them in their news for several weeks. See, for instance, "Sunday Times: kandidatskaja dissertatsija Putina - plageat." [Sunday Times: PhD 
Ethics misconduct, including sexual misconduct, is not related directly to academic process and is not confined to higher education institutions only, but can be found in other organizations as well. The issue of sexual misconduct in academia is not paid much attention in the media, except The Chronicle of Higher Education in the US.

Another phenomenon that can hardly be found in any reports by the selected media sources is an abuse of public property, despite the fact that many public higher education institutions in the US, the UK, and the RF own and manage large academic facilities, numerous other premises, and land. There is only one report in Newsru that presents a groom picture of spaces in student dormitories being leased to private businesses, immigrants, and even illegal aliens, while out-of-town students, entitled to free housing, are denied accommodations in these dormitories for the lack of space. Money received from businesses is perceived to be filling pockets of college administrators, including those responsible for student housing. The situation may be typical for state higher education institutions in Russia, located in large cities, where cost of renting is increasingly high and demand on square footage is growing.

Breach of contract is a more serious phenomenon of corruption than is normally considered. The number of students in the class, lecture time, faculty-to-student ratio, quality of libraries, laboratories, and other facilities and equipment, and accessibility of faculty are all points over which fraud may occur. Unclear rules and conditions of educational contract leave enough room for abuse and allow for corruption in academia. This aspect of the academic process is either left unattended or is not referred to as corruption by the media. Some reports on

dissertation of Putin - plagiarism] Newsru (March 26, 2006); and "Amerikanskie uchenye obvinili Putina v plagiate. Eto mozhet povlech' massovuju proverku dissertatsij rossijskih chinovnikov." [American scholars accused Putin in plagiarism. This may lead to a massive campaign of checking quality of doctoral dissertations defended by Russian bureaucrats] Newsru (March 27, 2006) 
quality of education and scandals around it may be found in the Russian media, including the conflict between students and the Department of Sociology in Moscow State University ${ }^{15}$ The media cares about credentials, when individuals buy fake degrees, but it cares little for breach of contract, when universities supply educational services below the announced quality.

Means used in corrupt activities to achieve certain goals include bribes, kinship, personal connections, reciprocity, and fraud. Bribes can be monetary and non-monetary, including durable goods and non-durable goods, services, and sex. Kickbacks as a form of delayed bribes can include direct payments, tuition waivers, registration fees, trips, vacations, services, gifts, office supplies and equipment. Often kickbacks are calculated as a percentage of the total contract value. Kinship includes relatives' discretion, access, and ability to influence decisions. Personal connections are good relations with people who are in a position of discretion, access, or ability to influence decisions. Reciprocity means exchange of favors. Means of fraud are fraudulent documents, including IDs, bank statements, and fraudulent claims.

Locus or areas and processes in higher education that become corrupted or are susceptible to corruption include access to higher education, academic process, graduation, credentials, licensing and accreditation, funding, faculty hiring and promotion, research, grants, and healthcare.

Corruption in access to higher education occurs or is connected to: standardized tests, regarded in lieu of the entry examinations; admission decisions, made by the members of admission committees and/or admissions offices; entry examinations, administered by the universities; sponsorship, donations, gifts, and contributions, including anonymous ones. In the

15 "Obshestvennaya palata prokontroliruet situaciju na sotsfake MGU” [Obshestvennaja Palata will take under control the situation in the Faculty of Sociology in MGU] Gazeta.ru 2007 (April 21). 
US, donations are not reported as possible bribes in exchange for admissions to prestigious universities, simply because this is "the way the system works." Fundraising, a recent trend in some British universities, is now discussed in the media, but is not associated with possible corruption in admissions. The same is characteristic of Russian higher education institutions. President of Moscow State University (MGU) Victor Sadovnichy reports that some new buildings on the University's campus were built thanks to generous donations of corporate sponsors. Sadovnichy also prizes himself for managing to triple faculty's salaries thanks to external sources of income. ${ }^{16}$

Corruption in the academic process occurs with unfair or biased assignment of positive and negative grades; unequal initial conditions for students, including additional time for test for ADD students, whose special needs are based on false or incorrect medical diagnoses; time spent on a student as a client or consumer of educational services, including office hours and consultations not held by professors.

Forms of corruption in graduation include gifts, graduation by petitioning, and organization of banquets by matriculating students for their professors. As follows from works of Rait (1931), Rashdall (1936) and Thelin (1982), these forms of corruption come from medieval universities and remain largely unchanged. They are considered quite innocent and are not paid much attention by the media.

Corruption linked to academic credentials includes provision of educational credentials, diplomas, transcripts, certificates, and other related documents by diploma mills; transfer of educational credits from a lower-quality institution or a diploma mill to a higher-quality or

16 "Sprosite Viktora Sadovnichego. On-line interv'ju rektora MGU Viktora Sadovnichego." [Ask Victor Sadovnichy. On-line interview with the rector of MGU Victor Sadovnichy] Gazeta.ru (May 6, 2007). 
higher-ranked institution; production, sale, and usage of fake diplomas that reproduce diplomas and other educational documents of accredited and commonly recognized universities. Diploma mills were known to exist in the decentralized and loosely coordinated US higher education for decades. ${ }^{17}$ In the RF, diploma mills are almost non-existent even now. However, quality of educational programs in some private colleges is below the standards set by the government. Also, fake diplomas are reported to be sold on the streets. ${ }^{18}$

Licensing and accreditation are procedures of quality control that are vulnerable to corruption. Provision of services below established standards makes higher education institutions pay bribes to state or regional accreditation agencies in order to gain or maintain accreditation and continue to stay in the educational business. This is typical for the RF, where colleges with poor quality of instruction have one year to improve or to be closed. ${ }^{19}$ The growing private sector in higher education shifts the media's attention from corruption in faculty-student relations to state-university relations. On the other hand, in the US, the government turns to the False Claims Act to encourage colleges to adhere to the proper teaching practices and provide quality educational services. ${ }^{20}$ Similar to Russia, diploma mills in the US pay bribes in order to gain

${ }^{17}$ See, for instance, Bartlett, T., and S. Smallwood. 2004. "Inside the multimillion-dollar world of diploma mills." The Chronicle of Higher Education, 50(42) (June 25): A8.

${ }^{18}$ MacWilliams, B. 1999. "Diplomas for sale on Moscow's streets: $\$ 800$ degrees from universities reflect the corruption of Russian higher education." The Chronicle of Higher Education 16 (July 16).

${ }^{19}$ Holdsworth, N. 2004. “'Quality Police' Axe Poor Colleges.” The Times Higher Education Supplement, 1627, (February 14): 12.

${ }^{20}$ Van Der Werf, M. 2006. Lawsuit U. The Chronicle of Higher Education, 52(48) (August 6): A23. Van Der Werf reports that instructors at Chapman University allege that the college encouraged early dismissals, and that as a result many students did not get the minimum classroom training required in several subjects. If the college admitted that it engaged in this practice, the suit says, it would have never been accredited, and never received millions of dollars in federal grants and student aid. 
accreditation. ${ }^{21}$ The government attempts to fight diploma mills ${ }^{22}$ while diploma mills defend their rights in the court of law. ${ }^{23}$ The Chronicle reports that "An unaccredited institution based in Wyoming is going to federal court to challenge an Oregon law that prohibits using a diplomamill degree to get a job. Kennedy-Western University argued in a complaint filed in July in U.S. District Court in Portland, Ore., that the law violates the First Amendment rights of its alumni by not allowing them to claim their degrees on their resumes." ${ }^{24}$ This self-proclaimed university is afraid of loosing its clientele due to the restrictions on using its worthless degrees. Problems of diploma mills and accreditation may also collide. ${ }^{25}$

Corruption in faculty hiring and promotion includes lack of objectivity in recruitment, bribes, nepotism, exchange of favors, pass-over, and discrimination. This topic is one of the least discussed. For instance, practices of employing ghost instructors in order to appropriate their publicly funded salaries are not described in the media. Some materials may be found in The Times Higher Education Supplement, pointing to low transparency and outdated procedures in faculty hiring and promotion in Italy, Spain, and the UK.

Corruption in research includes research fraud. Research fraud is discussed by the US and UK media sources, with the focus on the links of university researchers and medical and pharmaceutical industry. The discussion is bound around conflict of interest, misreporting or not

${ }^{21}$ Bartlett, T. 2006. "Fake university paid bribes for credentials." The Chronicle of Higher Education 52(30) (March 31): A14.

${ }^{22}$ Carnevale, D. 2004. "Federal and state officials discuss cracking down on online diploma mills." The Chronicle of Higher Education, 50(23) (February 13): A32.

${ }^{23}$ Foster, A. 2003. "Illinois professor shuts down his web site on 'diploma mills'." The Chronicle of Higher Education, 50(9) (October 24): A38.

24 "Diploma Mill Sues Over Diploma-Mill Law." The Chronicle of Higher Education 51(2) (September 3, 2006): A14.

${ }^{25}$ Bartlett, T. 2004. "Member of accrediting group has Ph.D. from 'notorious diploma mill'." The Chronicle of Higher Education, 50(30) (April 2): A29. 
reporting unfavorable results, and biasness of interpretations. ${ }^{26}$

Corruption in grants that includes embezzlement does not draw the attention of the media. This may be explained in part by the fact that most of the grants in higher education are research grants and because of the nature of research activities it is difficult to calculate the precise cost of the work performed and time spent on the grant. This is characteristic of US and UK systems. In the RF, the government is just starting to allocate research grants to few leading universities, after a significant break during the transition. Research institutes exist separately from higher education institutions, and hence, possible embezzlement in research grants is not related to higher education.

Corruption in healthcare and medical services provided by university hospitals include reduced time to a patient, i.e. client or consumer of medical services, as well as billing for medical services not rendered to patients. In the RF such kind of corruption in higher education is non-existent since higher education institutions do not offer medical services. In the US in many higher education institutions medical centers produce over half of the institution's revenue and the potential for abuse is significant. However, the media does not report on this aspect of corruption in higher education.

Interactions where corruption occurs include relations between state and university, business and university, faculty and students, faculty and administration, students and administration, and students and state. Corruption in state-university interactions includes misdeeds in funding, student financial aid, appropriation of federal and state grants, granting non-profit status, and taxation. Corruption in business-university relations includes research with intentionally biased results, provision of private educational loans on doubtful grounds, and

\footnotetext{
${ }^{26}$ Mangan, K. 2003. "Many medical professors who serve on review boards also have industry ties, study finds." The Chronicle of Higher Education (August 14).
} 
healthcare fraud. Corrupt activities between faculty members and students include all kinds of bribes, misconduct, as well as underpaid and free services that come from students. Corruption in faculty-administration relations finds its expressions in unfair treatment, promotions, and dismissals. The major form of corruption in students-administration relations is breach of contract, when the university administration fails to deliver quality educational services as abided by the contract. Finally, corruption in relations of state and students include financial aid fraud, when students defraud the government on their ability to pay, and legal status, when students use educational programs to gain and maintain their alien status in the country.

Rarely do media sources comment on such potentially corruptible practices as honoraria for invited speakers, who may also be key figures in allocating state funding and grants, making appointments to public offices, and having discretionary power over other important decisions. Here honoraria may play a role of a perfectly legal bribe. Such practices may constitute conflict of interest. Conflict of interest is highlighted, for instance, in the investigation of student loans in the US, where financial aid officers encourage students to borrow from certain preferred lenders, or in the discussions over potentially corrupt private tutoring services in the RF, where faculty members who sit on the admissions committees are also employed as private tutors for prospective students. At the same time the term of white collar crime is not used or applied in considering corruption in academia.

There are reports on cases in higher education that at first appear to be clear cases of corruption but can hardly fall into any of the established categories and can not be categorized as cases of corruption. For instance, The Chronicle of Higher Education reports on the decision of New York University to return money received as a donation, because the donor is being accused 
of bank fraud. ${ }^{27}$ Accordingly, the nature of the money is not clear and may well be criminal. However, this case does not imply corruption on the side of the University, especially since it made an ethically correct decision to return the donation.

Few other examples may be found in Newsu and include reports on an MGU student who owned and managed a brothel in Moscow and a group of ten individuals using a chemistry laboratory in MGU to produce illegal drugs. Neither of these cases can be classified as corruption in higher education, unless, for instance, as is in the latter case, it would be proven that the university administration was renting the laboratory to the drug producers without proper control over their activities, and furthermore, bribes or kickbacks were paid. Similar information comes from the Minister of Science and Education, who suggests testing all of the students, who's study is paid for by the state, for drug abuse. While pointing to a potentially large problem with usage of illegal drugs by students, this information does not relate directly to corruption in higher education.

\section{Comparing the findings by country}

As follows from media reports, some forms of corruption are region-specific while others are universal. Types of corruption are connected to the characteristics of the national systems of higher education (private, public, state). The general trend in the media is to reflect the growing concern about corruption in academia. In the US, more attention is now paid to fraud, plagiarism and cheating, while in the RF bribery in admissions and degree completion are in focus. The growing market of private educational loans in the US, which has increased tenfold over the last

${ }_{27}$ "We said from the time that the Yalincak family's legal issues became public that if the money was not theirs to give, that if it was ill gotten in some way, then the university would return it," said John Beckman, a spokesman for NYU. Leubsdorf, B. (2006). "NYU seeks to return 1.25-million gift." The Chronicle of Higher Education, 52 (June 16): A28. 
decade, rising from $\$ 1.7$ billion to $\$ 17$ billion, leads to different types of fraud in state-university relations. Fraudulent activities, in their turn, necessitate state and federal investigations. In the $\mathrm{RF}$, where educational loans, both private and state, are in their infancy and legislation is not detailed, this kind of fraud is virtually non-existent. At the same time, the traditionally corrupt admissions process receives the lion's share of the media's attention. The admissions decisions are made by faculty and are often corrupt. Half of all the places in public higher education institutions are funded by the state, which creates enormous pressure on faculty and raises the stakes as well as incentives for corrupt activities.

Access to higher education, expressed in terms of admission policies, is both restricted and broadened by corruption. Aspects of corruption in access to higher education discussed in the media in the RF and in the US are as follows. In the RF, students try to gain admission to a college. If they do it by illegal means, they defraud the university. There is no need to pay tuition in the governmentally funded programs, so the stakes are high. The measures to oppose prospective students defrauding the system include governmental control exercised through higher education institutions and law enforcement agencies.

In the US media, corruption in access to higher education is not discussed directly. However, there is a room for corruption in admissions and some of the corrupt actions are discussed without using terms "corruption" or "fraud." In the US, a large number of private universities, and especially fast growing private for-profit educational corporations, try to enroll students in their educational programs. One may find many cases when such higher education institutions defraud students in order to enroll them in the program or "to get them on board." The stake for the universities here is clear-students' tuition that often comes from federal, state, and private educational loans and grants. There are several mechanisms in place to prevent such 
a fraud, including accreditation procedures by the regional accreditation boards and an oversight by the Department of Education. However, these are either voluntary or incomplete.

Presumably, fraud takes place when: first, a prospective student is convinced by the university administrators, including admissions officers, that he can be successful in the program, while his previous academic records point to the opposite. For instance, a prospective student is offered to enroll in a college program without having a high school diploma, or to complete "an accredited MBA program" without holding a Baccalaureate. Here a prospective student is defrauded. Simply put, a consumer is offered a product he cannot consume. The college files for financial aid for the admitted student. The student starts accumulating financial debt on his educational loans. When he drops out of college because of unsatisfactory academic performance, he carries financial debt. Second, when student leaves, the college continues to collect financial aid from the government. In essence, money is streamlined from the student to a higher education institution in form of tuition and fees. The money comes from governmental and private sources. This constitutes fraud on the side of the higher education institution. The essence of this type of fraud is in the following: the government offers loans not to everyone, but to those capable to be successful in the college; the government only offers financial aid to enrolled students.

The missing link is private banks that provide educational loans. Providers of student loans compete for clients and try to maximize their profit by monopolizing the market. Collusion of banks with higher education institutions becomes almost inevitable. Such collusion would be inevitable even without monopolization of the educational loans market. The latest developments and investigations by the Attorney General of the State of New York confirm this. Private banks may even establish their own for-profit colleges through which they will issue and collect 
educational loans. This scheme will allow increasing the number of the customers. Repayment of educational loans is enforced by the law, i.e. banks are backed by the state. This provides guarantees to the banks-lenders. The risks of failures to refinance will be compensated for by the higher interest rates. Quite possibly, educational loans industry will be the next largest industry after the home loans and mortgages. The principal distinction is that in the case of home loans, home is a collateral, while in the case of educational loans, education can hardly play the role of collateral, since human capital is by definition indivisible from an individual.

According to news reports, corruption in admissions exists in both the RF and the US, but seems to be working in the opposite directions. While in the RF prospective students pave their way to a higher education institution with the help of bribes, in the US corrupt activities are oftentimes initiated from the side of a higher education institution that tries to attract students. Corruption in admissions takes place in the UK as well. Technical difficulties and numerous reported violations in the national standardized test lead to a biased picture of scholastic abilities of prospective students, and hence, to unfair or altered chances of entering higher education. ${ }^{28}$

Individual corruption in the US is generally restricted to research fraud and, though to a lesser extent, conflict of interest and sexual misconduct. In the UK, the major discussion of different aspects of institutional and individual forms of corruption is concentrated around the ongoing reform that targets the funding of higher education. Other issues include the credibility of the results of national examinations that affect admissions decisions and the research ethics.

In the RF, institutional corruption is discussed along with individual corruption or otherwise is not paid much attention. Major focus here is on bribery in admissions, academic

${ }^{28}$ See, for instance, Owen, G., and L. Peek. 2001. "Time cheats pass exams on the Net." The Times (June 2); Wachira, K. 1999. "Entrance exam helps foil cheats." The Times Higher Education Supplement (September 10); Williams, H. 2001. "Real lives: marked for life. So students bought stolen A-level papers." The Guardian (June 15): 6. 
process, graduation, as well as on the availability of diplomas for sale. Recent introduction of the national test and test-based admission decisions brings to fore issues of credibility of the test results and makes the discussion of access and equity more vivid.

There are certain aspects of corruption in each media source which are omitted. We think that omitted issues are country-related but not country-specific. For instance, in the US the discussion of institutional corruption misses the problem of diploma mills. This might be explained by the fact that the state does not guarantee quality of the degrees or the diplomas. Interestingly, the issue of diploma mills was given more attention in 1980s, when the federal government had conducted a series of investigations. Within the realm of individual corruption in US colleges, the missing aspects include bribery, possibly because there is not much of it in the faculty-student relations. In addition, many higher education institutions allow gifts for faculty members and staff as long as they do not represent conflict of interest.

As opposed to the US, media sources in the RF do not reflect on such an aspect of institutional corruption as fraudulent practices in athletics. This may be explained by the fact that intercollegiate athletics is not a big business in the country and in the region. Also, medical services and healthcare fraud in university hospitals are absent simply because higher education institutions do not render medical services. In the discussion of individual corruption, missing aspects include research fraud, because most of the research is done outside the nation's higher education institutions, within the Academy of Sciences (RAN); the leading universities are only involved in fundamental research where fraud is less common.

There is a difference in scope—national or international—of reporting on corruption in higher education by specialized and non-specialized editions in each of three countries. In the US, the specialized source comments on corruption in higher education internationally, while the 
non-specialized source comments nationally. The same is characteristic for UK sources. In the RF, the specialized edition comments nationally, while the non-specialized source comments internationally. The following explanation may be offered in this regard. The specialized sources in the US and the UK, i.e. The Chronicle of Higher Education and the Times Higher Education Supplement, respectively, focus exclusively on higher education, having their professional staff report on the problems of the industry. As globalization and internationalization of higher education develop, reports on higher education worldwide become necessary. At the same time, the leading nationwide news editions, including The New York Times and The Guardian, address mostly national higher education, as they reach out to the national reader. Here in-depth coverage of particular issues in higher education, especially in international and comparative perspectives, appears unnecessary.

In the RF, the situation is a bit different. The quasi-specialized edition Gazeta.ru has but a special section devoted to education, and higher education in particular, along with several other sections. This may explain the lack of in-depth investigations or extended analytical reports. The reports are dedicated to domestic problems, omitting the issues of higher education in other countries. The specialized educational edition Uchitel'skaya Gazeta ${ }^{29}$ is focused entirely on the issues of secondary education, and hence is not included in the analysis. Analytical work may be found in few newly established journals with the focus on higher education, but these are scholarly publications. In a different way from Gazeta.ru, the major news media source Newsru comments internationally. The secret is that this news edition often reprints brief informative reports that appear in the foreign media. The authorized reprints with proper on-line referencing are selected based on the promise of attracting the reader. These include reports on corruption in

${ }^{29}$ The Teachers' Newspaper 
higher education worldwide.

Forms of corruption in higher education in the US emphasize state-university relations. Fraud is oftentimes the product of the grey area in the legislation. At the same time issues of fraud are relatively easy to move to court since the government is involved and the state interests are at stake. Traditionally, in the US many issues are decided through the judiciary branch of the government. Accordingly, the media reports on the specific legal cases, withstanding from making generalizations.

In the RF, where judiciary branch is relatively weak, most attention is paid to unfair admissions to governmentally funded places in public higher education institutions and bribery in academic process, because these are the most obvious forms of corruption. Bribes are presumed to have monetary form, which is traditionally least acceptable and not well-tolerated by the society. At the same time nepotism and cronyism are often overlooked, while these forms of corruption might have more presence in higher education and more impact on the admissions policy, than bribes.

Cheating among students is given attention equally by the media in all three nations. The US and the UK sources are more concerned with plagiarism than their counterparts in the RF. Fraud and embezzlement in research grants is a new topic in Russian media, while in the US it was in focus for a few years. Problems of corruption in licensing and accreditation are characteristic of both the US and the RF. In the US, accreditation is still a voluntary process and the US Department of Education is attempting to claim a higher authority in this realm. In the RF, issues of state-administered obligatory licensing and accreditation are of high importance due to the development of private sector in higher education. Corruption in business-university relations, including pharmaceutical and high-tech industries, is mostly reflected in the US sources. 
In The Chronicle of Higher Education, the word corruption is applied almost exclusively to international educational practices. US media sources are very cautious about using explicit terminology as applied to the domestic problems in education, avoiding words corruption, bribery, and fraud. For instance, the topic of research fraud may be found in only one or two publications a year, while research misconduct may be seen in around five to ten publications a year. Corruption and fraud are routinely replaced with the terms misconduct and breach of integrity. At the same time reports on fraud related to cheating and plagiarism are plentiful. Areas of access and accreditation are left almost unattended. The issue of accreditation, voluntary in the US, does not pair with abuse, bribery, fraud, corruption, scandal, or scam. The same is true for admissions to colleges.

As compared to the other media sources studied in this paper, The Chronicle of Higher Education is the richest and most comprehensive source of information about higher education, with the largest scope of problems and issues highlighted in its reports.

Similar to the US sources, in The Times Higher Education Supplement the term bribery is only applied to foreign higher education. Bribery is reported in Kyrgyzstan, India, Nigeria, Russia, Venezuela, Vietnam, Ukraine, and some other countries and is not observed in the European Union countries, Canada, or the US. ${ }^{30}$ Most of the bribery in developing and transition economies is found in admissions to higher education. A certain political agenda can be traced through the publications. In Russia, bribes in admissions are reported, apparently based on the

${ }^{30}$ See, for instance, Holdsworth, N. 2006. "Minister: Blow The Whistle On Bribes." The Times Higher Education Supplement, 1573 (January 24): 17.; Orozco, J. 2006. "Access plans have yet to show results." The Times Higher Education Supplement, 1767 (November 2): 11.; Hayton, B. 2006. "Rug pulled from under cheats." The Times Higher Education Supplement, 1752 (July 21): 10.; Rich, V. 2006. "Passing Exams Is A Real Gift." The Times Higher Education Supplement, 1730 (February 17): 13.; Raghavendra, V. 2006. "Indian Exam Racket." The Times Higher Education Supplement, 1729 (February 13): 13. 
fact that the nation is in the process of introducing the standardized test that would replace entry examinations. Also, at least half of all the college places are funded by the government. In Belarus, according to The Times Higher Education Supplement's reports, antigovernment protests by the students and educators, including dissidents, are most popular, pointing to the authoritarian political regime. ${ }^{31}$ The problem of diploma mills is related to the US, as Britain has its stakes in both issues of free trade and in accreditation. In China, fake educational certificates are in the focus. ${ }^{32}$ This may be explained by the large population and intensive migration, including into the US and the European Union.

Problems of quality control and licensing were reported for Russia as well. ${ }^{33}$ This may be explained by the fact that Russian higher education is still characterized by the high level of centralization and control. Nepotism is being reported in colleges in Italy, Spain, and the UK, as related to faculty hiring and promotion and student enrollment and retention. There are plenty of reports on fraud in higher education, including research fraud, cheating, plagiarism, and embezzlement. These reports, presented in The Times, highlight fraud in the UK, the US, and other countries. It appears from the British media sources, that most represented forms of corruption in the country's educational system are cheating, plagiarism, and gift-giving.

31 The Times reports that detained Belarusian scientist Yury Bandazheuski, former rector of Gomel Medical University and an Amnesty International "prisoner of conscience", has been released on parole. He became eligible for parole earlier this year, having served two thirds of his eight-year sentence, but his application was denied, seemingly because he refused to admit to the charges against him. Professor Bandazheuski was convicted of taking bribes from university entrance candidates. Bandazheuski said that the charges of bribery were politically motivated and that his real "offence" was his research on the long-term medical consequences of the 1986 Chernobyl nuclear accident. Rich, V. (2005). "Jailed Scientist Granted Parole." The Times Higher Education Supplement, 1707 (September 3): 10.

${ }^{32}$ See, for instance, Maslen, G. 2005. "Trade In Fake Papers Soars.” The Times Higher Education Supplement, 1694 (June 7): 12.

${ }^{33}$ See, for instance, Holdsworth, N. 2004. "'Quality Police' Axe Poor Colleges.” The Times Higher Education Supplement, 1627 (February 14): 12. 
In general, level of comprehensiveness of the reports on corruption in higher education that may be found in The Times Higher Education Supplement is not as high as that in The Chronicle of Higher Education.

The media reflects on three different systems with different access policies. US sources report corruption in higher education in the RF based on the information obtained from the Russian news sources, without specifying that education is free for over half of all students and that public funding of colleges is one of the fundamental grounds for corruption in admissions to exist. At the same time, US sources do not mention the widespread practice of private donations, gifts, and charitable contributions to universities that exist in the nation. Such practices are considered a norm, as they were at the very core of establishing higher education institutions and are not challenged as doubtful even now.

Russian sources do not specify anything about the US higher education, with the information presented in the reports being very limited, partial, and highlighting major news points. Such partiality allows for taking reported cases of corruption out of the context. The analysis of different forms of corruption in the US higher education is absent. In the RF, when institutional corruption is mentioned, it is always paired with individual corruption. This contrasts with the US, because it tends to focus on institutional corruption.

In the UK, where virtually all higher education is public and stakes of being admitted to a higher education institution are high, corruption in admissions is not reported, except for cheating, irregularities, and technical failures in the national test. This seems to be doubtful at first, because the cost of education is much higher than the recently increased fees. Nevertheless, it is possible, if one is to take into account a sufficient number of places in colleges to satisfy public demand and the role of the standardized test score as the only criterion in admissions 
decisions.

Trends in time in each category more or less reflect the trends in the higher education industry. Private educational loans in the US, education fees in the UK, and standardized examinations in the RF are all in the news along with cases of corruption that accompany these changes and reforms. In general, more attention is paid to different aspects of corruption in the media now than it was at the beginning of the study period. The dynamics of reporting different aspects of corruption in the media are presented in Figures 1 to $5 .^{34}$

/Figures 1-5 appear here/

The Chronicle of Higher Education pays most attention to such phenomena as fraud, cheating, plagiarism, and embezzlement, with fraud being on the rise thanks, first of all, to the series of investigations lead by Mr. Cuomo. Among means of corruption, fraud is the leading type for the US, while bribes are most common means of corruption overseas. According to the source, most instances of corruption may be found in state-university and student-university relations. The issue of educational credentials fraud and diploma mills appears to be regaining popularity, especially in 2002, 2003, 2004, and 2007. In line with The Chronicle of Higher Education, The New York Times focuses on fraud as both a phenomenon and a mean of corruption, and on educational credentials.

The Times Higher Education Supplement reports mostly cheating and nepotism domestically and bribery and nepotism internationally, both being connected to the issue of

${ }^{34}$ The data for 2007 were prorated at 1.33 , since the real data analyzed for this year are for the period of January 1, 2007 to September 30, 2007. This was made under the assumption that the media reports are not season-related but smoothly distributed along the one-year period. 
access to higher education. Many other areas where corruption may potentially exist are left unattended. The Guardian points to cheating, plagiarism, and fraud, in academic process, research, and access to higher education. The number of reports over the last decade appears to be minimal.

Gazeta.ru pays most attention to bribery, extortion, and fraud that takes place in academia, and may be found in admissions to higher education institutions, in academic process, in issuing educational credentials, and in licensing and accreditation. Accordingly, most of corruption is found in interactions between faculty and students and state and universities. The newspaper also publishes letters from the readers, including ones focused on different aspects of corruption in higher education. Newsru publishes news about corruption in higher education that mostly contains bribery in admissions. A more recent trend is discussing fraud linked to educational credentials and licensing and accreditation. Similar to Gazeta.ru, Newsru reflects on corruption in faculty-students and state-university relations. Increasing awareness of the public about the credentials fraud indicates that the public finally came to understanding that knowledge is of value, not certificates.

The differences between media reports are not language-specific, i.e. English-language media in the US and in the UK reflect on the country-specific aspects of corruption. The same is true for the Russian-language sources in the RF.

It is difficult to establish a strong positive correlation between the media coverage of corruption in higher education in each of the three countries and the level of corruption perceived to be characteristic for the society. The surveys by Transparency International and by the World Bank picture Russia as a very corrupt country. In the 2001 survey by the World Bank, the RF was $142^{\text {nd }}$ out of 160 countries. According to the Corruption Perceptions Index (CPI), the RF 
was $71^{\text {st }}$ out of 102 . In 2006 , the RF was in $121^{\text {st }}$ place with the score of 2.5 . At the same time the recent survey conducted by the Transparency International and presented in November of 2006 places the US at $20^{\text {th }}$ position with the corruption score of only 7.3 out of 10 possible, where 10 would mean no corruption at all and 1 indicates the highest level of corruption. The UK is least corrupt, occupying the $11^{\text {th }}$ position. ${ }^{35}$ The statistical data on corruption in higher education in the US and in the UK could not be found. The RF is quite unique in this sense. The scope and major forms of corruption in higher education reflected in the media correlate with the results of polls and surveys on corruption, including those conducted by the INDEM foundation. ${ }^{36}$ The data presented by INDEM indicate an increase in corruption in higher education for the period of 2001 to 2005.

\section{Conclusion}

Corruption in higher education receives good coverage in the media. The level of transparency is high enough to highlight the issue, its significance, scale and scope, and variety of forms in which it manifests itself, and inform the general public of its prevalence, patterns, and forms. However, the positive effect of such a high level of transparency and open discussion in the media on the level of corruption in higher education has yet to be seen.

Corruption in higher education, and the way it is reflected in the media, appears to be consistent with trajectory and pace of reforms that take place in higher education industry in the US, the UK, and the RF. Introduction of college fees in the UK, reduction of governmentally

${ }^{35}$ Transparency International 2006. Corruption Perceptions Index. Retrieved from http://www.transparency.org/policy_research/surveys_indices/cpi

${ }^{36}$ See Satarov, Georgy. 2006. Corruption Process in Russia: Level, Structure, Trends. In Diagnostics of Corruption in Russia: 2001-2005, ed. G. Satarov. INDEM Foundation. Retrieved from http://www.indem.ru/en/publicat/2005diag_engV.htm 
funded places in the RF, and the growing significance of private educational loans in the US, all lead to an increase of corruption in access to higher education.

The continuing massification of higher education with increasing enrollment rates in all three countries, as well as the emergence of for-profit sector, necessitate more control and coordination on the side of the government, educational institutions, and the public. Growing concerns over the quality of educational services lead to an increase in reporting bribery, fraud, cheating, plagiarism, diploma mills, breach of contract, and other forms of misconduct. The processes of internationalization and globalization of higher education put an emphasis on such aspects of corruption as credentials fraud and research fraud.

Socio-economic context of educational reforms and changes in each country leaves its print on major forms of corruption in higher education. For instance, in the RF, economic transition and sharp decline in salaries of college faculty lead to an increase in bribery and nepotism. In the US, growing competition between higher education institutions leads to an increase in fraud associated with student financial aid.

Lastly, growing levels of transparency and information flow lead to a better understanding of different forms of corruption and its scope and scale. The media plays a primary role in highlighting the issue. However, media reports are focused on corruption per se, and often on its causes, but do not offer solutions or ways in which the public can resist corruption.

\section{References}

Anderson, Martin. 1992. Impostors in the Temple: American Intellectuals Are Destroying Our Universities and Cheating Our Students of Their Future. New York: Simon and Schuster. 
Anderson, Melissa. 1999. Uncovering the Covert: Research on Academic Misconduct. In Perspectives on Scholarly Misconduct in the Sciences, ed. J. Braxton. Columbus, OH: Ohio State University Press.

Anderson, Melissa. 2001. "The Complex Relations between the Academy and Industry: Views from the Literature." Journal of Higher Education, 72(2): 226-246.

Anechiarico, Frank, and James Jacobs. 1995. The Pursuit of Absolute Integrity: How Corruption Control Makes Government Ineffective. Chicago: University of Chicago Press.

Bardhan, Pranab. 1997. "Corruption and Development: a Review of Issues." Journal of Economic Literature 35: 1320-1346.

Eckstein, Max. 2003. Combating Academic Fraud. Towards a Culture of Integrity. Paris: IIEP. Hallak, Jacques, and Muriel Poisson. 2002. Ethics and Corruption in Education. Paris: IIEP. Hallak, Jacques, and Muriel Poisson. 2007. Corrupt Schools, Corrupt Universities: What Can Be Done? Paris: IIEP.

Heyneman, Stephen, 2004. "Education and Corruption." International Journal of Educational Development 24 (November): 637-648.

Johnston, Michael. 1996. "The Search for Definitions: The Vitality of Politics and the Issue of Corruption," International Social Science Journal, 149: 322.

Klitgaard, Robert. 1986. Elitism and Meritocracy in Developing Countries. Baltimore: John Hopkins University Press.

Krueger, Anne. 1974. “The Political Economy of a Rent-Seeking Society.” American Economic Review 64(3): 291-302.

Miller, Seumas, Peter Roberts, and Edward Spence. 2005. Corruption and Anti-Corruption: An Applied Philosophical Approach. Upper Saddle River, NJ: Prentice Hall. 
Milovanovic, Michael. 2001. "Endogenous Corruption in Emerging Industrial Relations,” The Hungarian Academy of Sciences, 2001. Retrieved May 12, 2002, from www.policy.hu/milovanovic/corruption.html

Noah, Harold, and Max Eckstein. 2001. Fraud and Education: the Worm in the Apple. Oxford: Rowman \& Littlefield.

Nye, Joseph. 1967. "Corruption and Political Development: a Cost-Benefit Analysis.” American Political Science Review 61(2): 417-427.

Osborne, Denis. 1997. “Corruption as Counter-Culture: Attitudes to Bribery in Local and Global Society.” In Corruption: The Enemy Within, ed. B. Rider. Dordrecht: Kluwer.

Petrov, Georgy, and Paul Temple. 2004. "Corruption in Higher Education: Some Findings from the States of the Former Soviet Union.” Higher Education Management and Policy 16(1): 82-94.

Rait, Robert. 1931. Life in the Medieval University. Cambridge: Harvard University Press.

Rashdall, Hastings. 1936. The Universities of Europe in the Middle Ages: Salerno, Bologna, Paris. Vol. I. In The Universities of Europe in the Middle Ages, ed. B. Emden and M. Powicke. Oxford: Clarendon Press.

Rashdall, Hastings. 1936. The Universities of Europe in the Middle Ages: Italy, Spain, France, Germany, Scotland, etc. Vol. II. In The Universities of Europe in the Middle Ages, ed. B. Emden and M. Powicke. Oxford: Clarendon Press.

Rashdall, Hastings. 1936. The Universities of Europe in the Middle Ages: English Universities Student Life. Vol. III. In The Universities of Europe in the Middle Ages, ed. B. Emden and M. Powicke. Oxford: Clarendon Press. 
Rose-Ackerman, Susan. 1978. Corruption: A Study in Political Economy. New York: Academic Press.

Sayed, Taleh, and David Bruce. 1998. "Police Corruption: Towards a Working Definition," African Security Review 7(1): 1. Retrieved May 20, 2002, from http://www.iss.co.za/ASR/7No1/SayedBruce.html

Segal, Lydia. 2004. Battling Corruption in America's Public Schools. Boston: Northeastern University Press.

Thelin, J. 1982. Higher Education and Its Useful Past. Cambridge, MA: Schenkman Publishing Company.

Tirole, Jean. 1992. "Collusion and the Theory of Organizations." In Advances in Economic Theory, ed. J. Laffont. Sixth World Congress, Vol. 2. Cambridge: Cambridge University Press.

Treisman, Daniel. 2000. "The Causes of Corruption: A Cross-National Study.” Journal of Public Economics 76: 399-457.

Waite, Duncan, and David Allen. 2003. "Corruption and Abuse of Power in Educational Administration." The Urban Review 35(4): 281-296.

Washburn, Jennifer. 2005. The Corporate Corruption of American Higher Education. New York: Basic Books.

Weber, Max. 1978. Economy and Society. Berkeley, CA: University of California Press.

White, George. 1996. "Corruption and the Transition from Socialism in China.” In The Corruption of Politics and the Politics of Corruption, ed. M. Levi and D. Nelken. Oxford: Blackwell.

Wilson, James. 1975. “The Rise of the Bureaucratic State.” In Public Policy, ed. S. Theodoulou 
and M. Cahn. Boston: Kluwer. 
Table 1

Criteria used and classification of corruption in higher education

Phenomenon. What takes place?

Bribery of all types and forms

Nepotism: kinship

Favoritism: preferential treatment

Fraud: research fraud, healthcare fraud, non-compliance, managed and biased information flow Embezzlement: from the university, by the university

Cheating: by students, prospective students

Plagiarism: by students, faculty

Ethics misconduct, including sexual misconduct

Breach of contract

Means. What means are used in corrupt activities to achieve certain goals?

Bribes: monetary, non-monetary (services etc.)

Kickbacks: monetary (normally a percentage of the total contract value)

Kinship: relatives

Personal connections: relations

Reciprocity: exchange of favors

Fraud: fraudulent documents, claims,

Locus. What are the areas and processes that get corrupted?

Access to higher education: tests (SAT, CET, TOEFL, GRE, GMAT, LSAT, GSE), admission decisions, entry examinations, donations, gifts, corporate sponsorship

Academic process: grades, additional time for ADDs, time to a client/consumer (student)

Graduation: gifts, petitioning, banquets, etc.

Credentials: diploma mills, transfer of credits, fake diplomas

Licensing and accreditation: provision of services below established standards (have to pay)

Faculty hiring and promotion: bribes, nepotism, expectation of favors, passovers,

discrimination

Research: fraud

Grants: embezzlement

Healthcare: time to a client/consumer (patient)

Interactions. What are the interactions, relations where corruption takes place?

State-university: funding, student financial aid, grants, non-profit status, taxation

Business-university: research with biased results, educational loans, healthcare fraud

Faculty-students: all kinds of bribes, misconduct, underpaid and free services

Faculty-administration: unfair treatment, promotions, dismissals

Students-administration: breach of contract

State-students: financial aid fraud, aliens

Source: completed by the author 


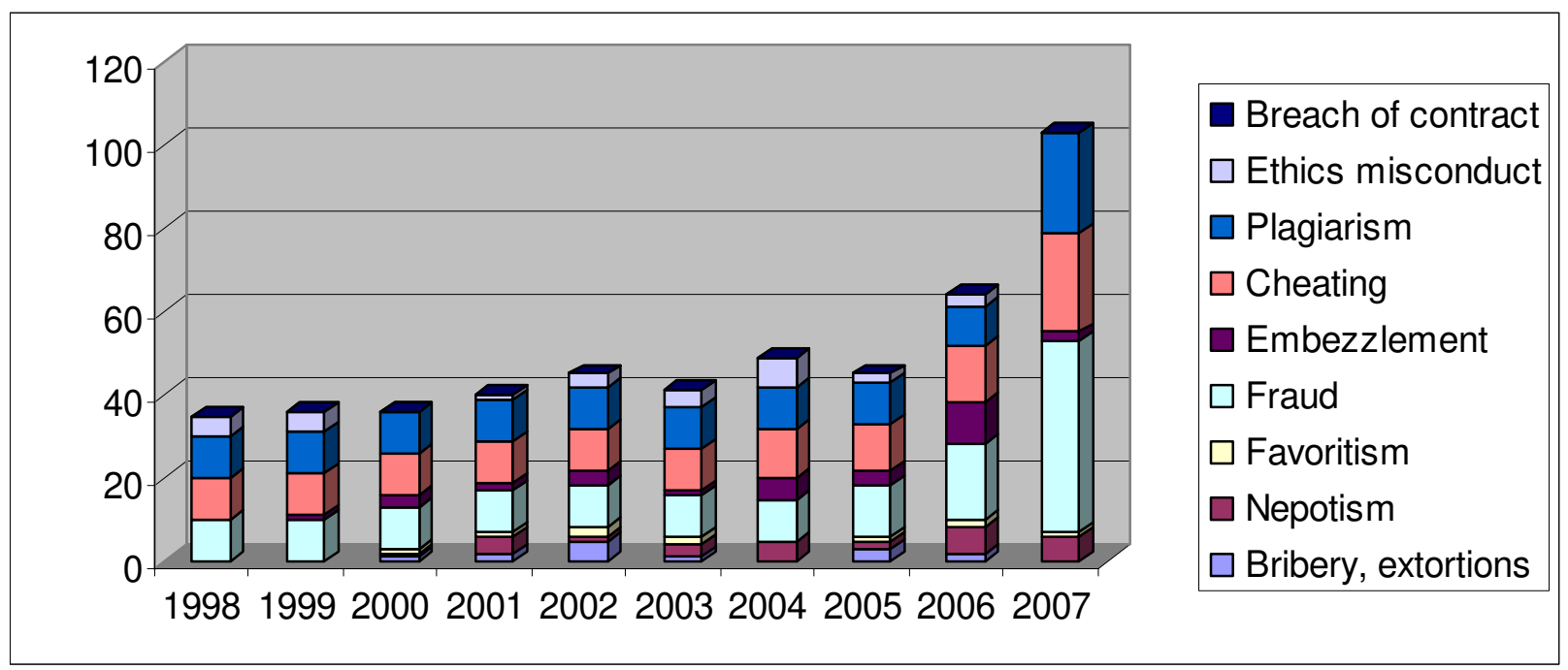

Figure 1. Dynamics of The Chronicle of Higher Education reports on corruption in higher education by phenomenon, 1998-2007 


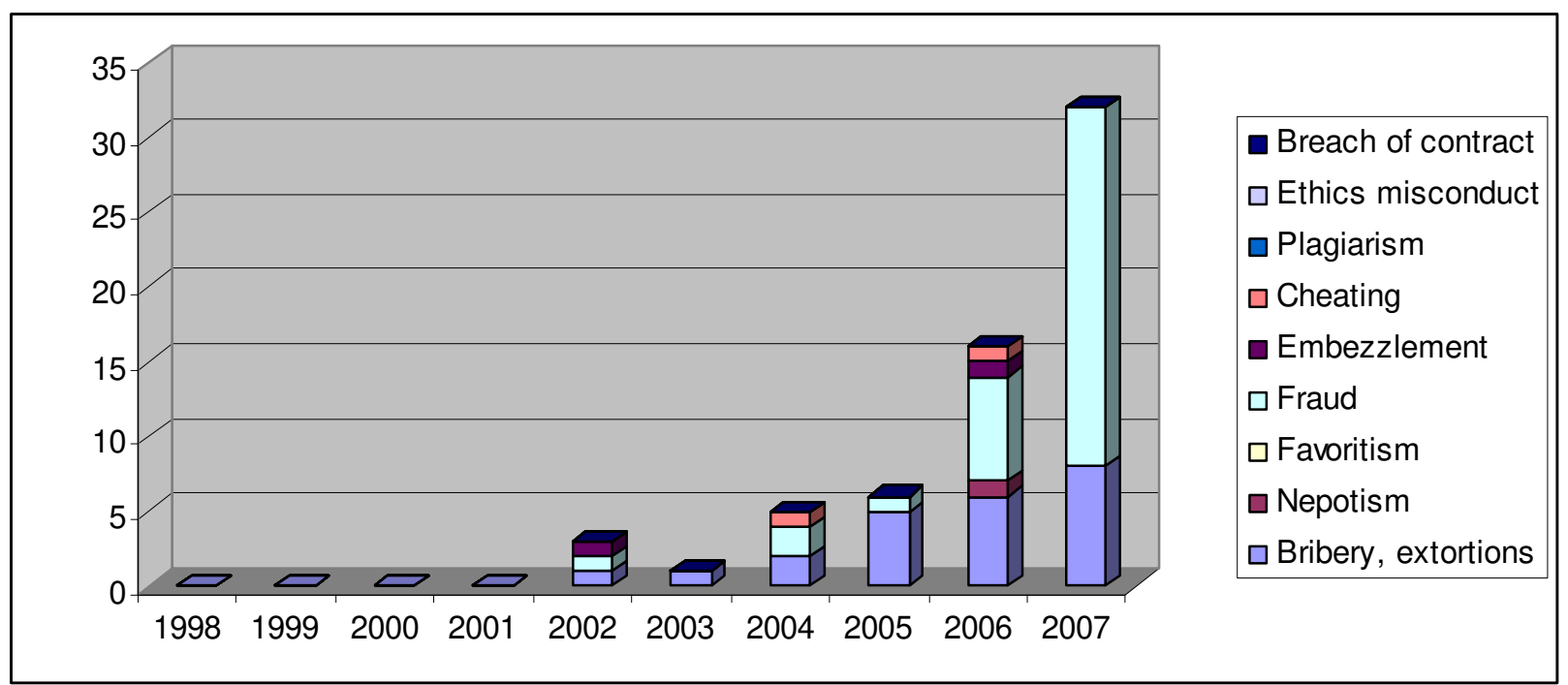

Figure 2. Dynamics of Gazeta.ru reports on corruption in higher education by phenomenon, 1998-2007 


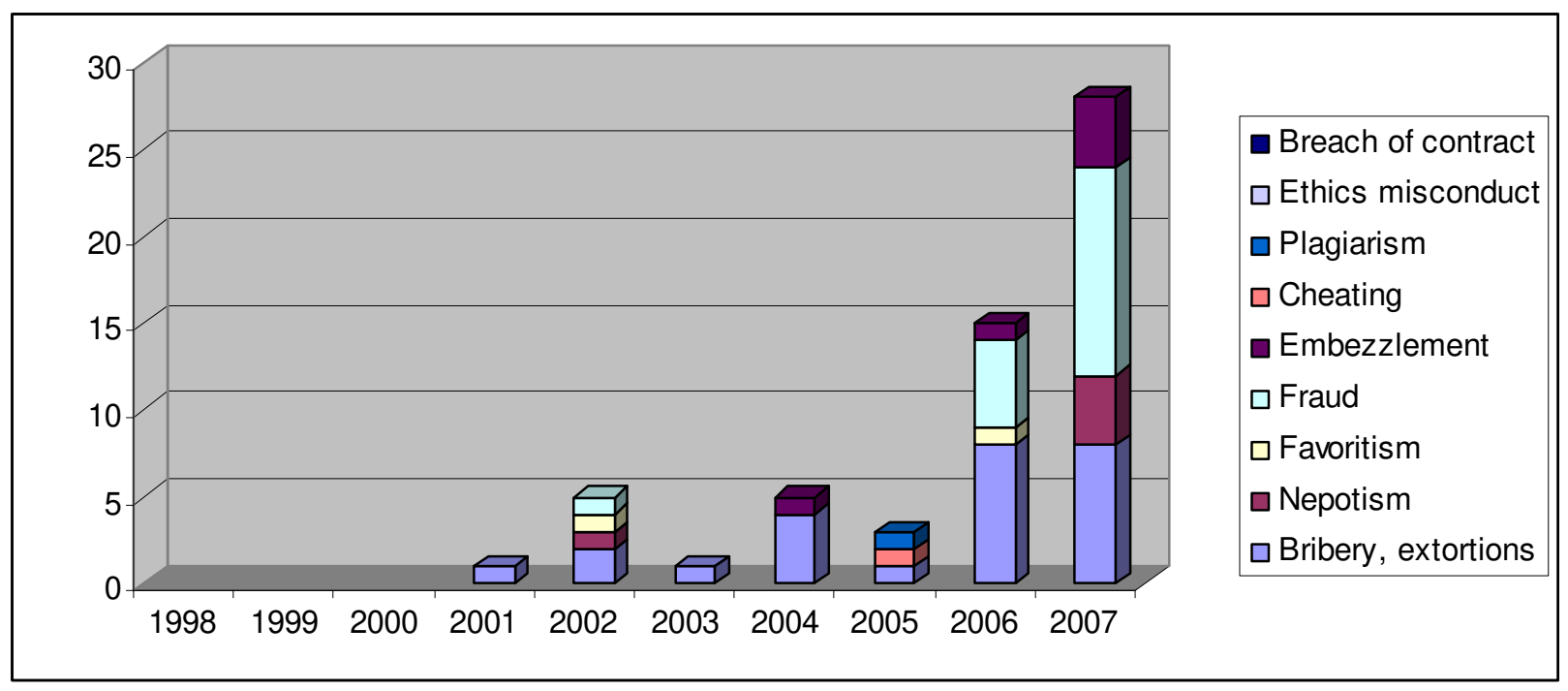

Figure 3. Dynamics of Newsru reports on corruption in higher education by phenomenon, 19982007 


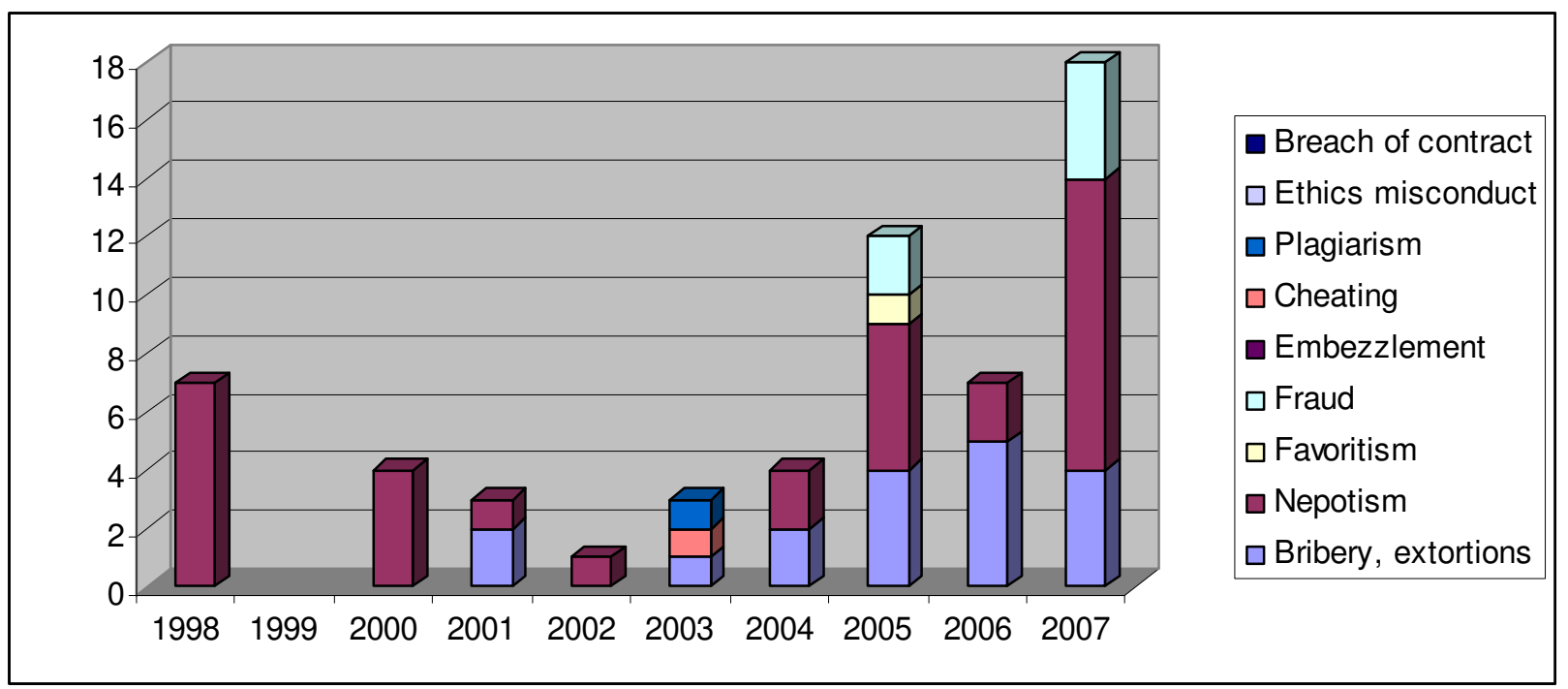

Figure 4. Dynamics of The Times Higher Education Supplement reports on corruption in higher education by phenomenon, 1998-2007 


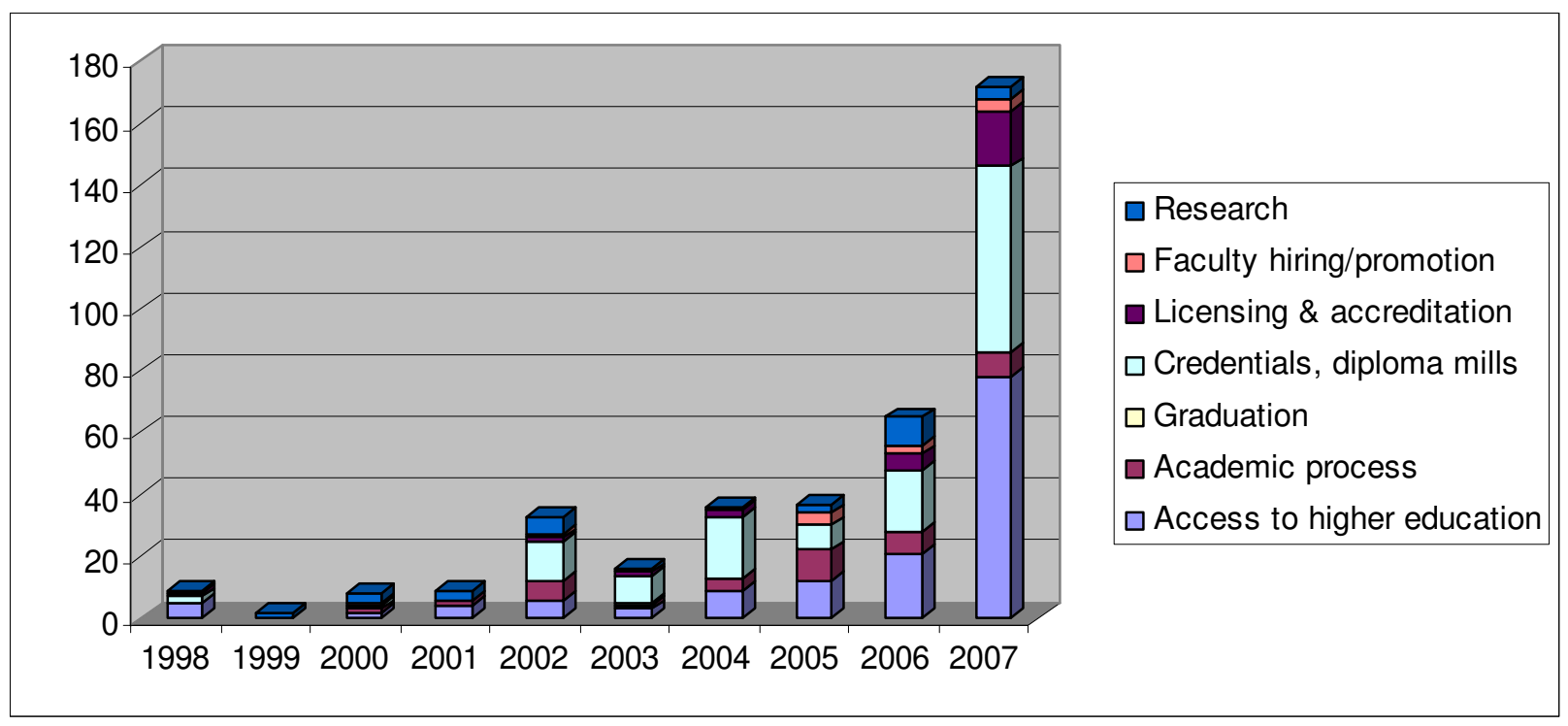

Figure 5. Dynamics of media reports on corruption in higher education by locus, 1998-2007 